Bryn Mawr College

Scholarship, Research, and Creative Work at Bryn Mawr College

Education Program Faculty Research and

Scholarship

Education Program

2008

\title{
Returning to the Mirror: Reflections on Promoting Constructivism in Three Educational Contexts
}

Alison Cook-Sather

Bryn Mawr College, acooksat@brynmawr.edu

Let us know how access to this document benefits you.

Follow this and additional works at: http://repository.brynmawr.edu/edu_pubs

Part of the Education Commons

\section{Custom Citation}

Cook-Sather, Alison. "Returning to the Mirror: Reflections on Promoting Constructivism in Three Educational Contexts." Cambridge Journal of Education 38, no. 2 (2008): 231-245.

This paper is posted at Scholarship, Research, and Creative Work at Bryn Mawr College. http://repository.brynmawr.edu/edu_pubs/25

For more information, please contact repository@brynmawr.edu. 


\title{
Returning to the Mirror:
}

\section{Reflections on Promoting Constructivism in Three Educational Contexts}

\author{
Alison Cook-Sather \\ Cambridge Journal of Education, 38, 2 (June 2008), 231-245
}

Reflective practice is a mode that integrates or links thought and action with reflection. It involves thinking about and critically analyzing one's actions with the goal of improving one's professional practice. Engaging in reflective practice requires individuals to assume the perspective of an external observer in order to identify the assumptions and feelings underlying their practice and then to speculate about how these assumptions and feelings affect practice.

$$
\text { - Imel, 1992, p. } 1
$$

A postmodern view of reflection opens the possibility of an understanding of reflection that admits of ongoing movement, change, and interaction, so that "success" in reflective practice is a matter of agility, mobility, flexibility, and, importantly, of the interdependence of one's movements with those of others on and beyond the reflected scene.

- Lesnick, 2005, p. 38

Since the early 1980s, educators have argued that reflection is an essential dimension of good pedagogical practice (Colton \& Sparks-Langer, 1990; Richert, 1990; Rudney \& Guillaume, 1990; Schön, 1983; Zeichner \& Liston, 1987), and in the early $21^{\text {st }}$ century, there have been several efforts to recast traditional notions of reflective practice in light of contemporary and postmodern insights (Lesnick, 2005; Rodgers, 2002a, 2002b). Although opportunities for reflection of any kind are not generally built into the "structure of teaching" (Elbaz, 1987, p. 45), advocates of reflective practice argue that, in the absence of reflection, one runs the risk of "relying on routinized teaching" and "not developing as a teacher or as a person" (Reiman \& Thies-Sprinthall, 1998, p. 262) and, particularly in contemporary times, of failing to "stand up to the demands of teaching...diverse people in diverse, difficult settings" (Lesnick, 2005, p. 33). Being a reflective practitioner means not only developing the disposition to reflect on practice 
and on the complexities of relationships and approaches within different teaching contexts but also finding the words to express those reflections to others (Yinger, 1987).

In the spirit of these arguments, I offer the present reflection on my own efforts as a teacher to support a constructivist approach to learning for three different groups of learners across three different contexts. While "constructivism" means different things to different people (Davis \& Sumara, 2002; Kroll \& Galguera, 2005; Shapiro, 2002, 2003), constructivist approaches have in common the belief that learners actively and distinctively construe and construct their own understandings in relationship and in context (Davis \& Sumara 2002; Dewey, 1964; Duckworth, 1987) and adapt their understandings and future choices for action based on the sense they make through those processes of construal and construction (Kroll, 2005; von Glaserfeld, 1996). The learning process that unfolds when understanding is constructed neither occurs nor is completed in a single event (Dreier, 2003). Rather, learning and understanding of that learning take place over time, and "learning changes not just what the learner knows...but also who the learner is" (Wortham, 2004, p. 716; see also Cook-Sather, 2006b; Packer, 2001). Valuing the learner's emotional as well as intellectual engagement, constructivism is not a theory about how to teach, but it reminds us that the learner — in all her complexity - "must be at the center as we think about our subject matter, our curriculum, and our pedagogy" (Kroll, 2005, p. 58).

Reflective practice among teachers and constructivist approaches to learning have in common a commitment to the ongoing effort necessary to strike a balance between engaged action and more distanced analysis, between what is already known and what needs to be apprehended, between who one is and who one might become - all explored both individually and in relation to others. Indeed, those who engage in constructivist approaches to learning take the first steps toward becoming reflective practitioners in whatever realm they choose to enter. To try to make conscious and explicit the interconnected efforts I have made to engage in reflective practice as a teacher and the attempts I have made to support constructivist learningand preparation to become reflective practitioners-among the learners with whom I have worked, I analyze in the following pages several assignments I have designed for differently positioned learners, including: a class of college sophomores in an intensive reading and writing course; a group of undergraduates seeking certification to teach at the secondary level; and teams of college juniors, faculty members, librarians, and instructional technologists engaged in 
professional development workshops-all within the context of a liberal arts college in the northeastern United States.

Referring to the assignments I have developed in each context, I analyze the particular kinds of structures, challenges, and supports I try to provide learners with the goal of surfacing the convictions I hold about learners' identities and capabilities. My goal is to identify underlying pedagogical principles that inform my practice across contexts not only to make clearer for myself and others what guides my practice but also, in an effort to acknowledge the evolving and interdependent nature of this work, to articulate the new challenges this analysis poses for me._In other words, I attempt to show how my reflections on the "assumptions and feelings" (Imel, 1992, p. 1) that underlie my practice are returned to me in what Lesnick (2005) calls "the mirror in motion," which captures, in turn, my own "movement, change, and interaction" (p. 38).

\section{Assignments that Aim to Support Constructivism}

The purpose of the following examples of assignments is to invite and support constructivism as defined in the previous section. The first assignment is drawn from an intensive reading and writing course for college sophomores, the second from the penultimate course completed by undergraduate seniors seeking certification to teach at the secondary level, and the third from a summer workshop designed to support teams of college juniors, faculty members, librarians, and instructional technologists working to integrate technology into teaching in meaningful ways.

\section{Example One: The Multiple-Perspectives Assignment}

A course I have taught through the College Seminar Program at Bryn Mawr College, "Finding the Bias: Tracing the Self Across Contexts," takes an interdisciplinary approach to the development of critical thinking and writing skills. Designed in collaboration with faculty colleagues in history and literary studies, it draws upon but also complicates traditional disciplinary distinctions and challenges the college sophomores who enroll in the course to explore and to problematize the traditional separation of the personal and the academic in college study. The title of the course builds upon the figurative meaning of bias-a slant, a preference, a perspective, a prejudice - to illustrate how, in academic practice and in life, finding a bias is the 
process of deciding how one will cut across — take an angle of vision on — various facts, ideas, experiences, and contexts - and discerning how others have done so. In challenging learners to develop their critical and creative abilities, we ask them not to separate and distance themselves from what they study and who they are but rather to recognize, name, and trace a variety of biases along which they and we live, think, and write. The texts we assign in this course all productively violate the boundaries of academic and personal writing and of specific disciplines.

The writing assignments for the course use these texts as models of how to complicate any simple delineation between the personal and the academic, and between the genres of fiction, history, educational theory, autobiography, and anthropology. (See Cook-Sather, 2006a and 2003 b as well as Cook-Sather, Rowe \& Shore, 2001, for other discussions of this course.)

The multiple-perspectives assignment within this course requires students to tell the same "true" story-a story of an experience from their own lives-from three different angles of vision - their own and two others' - and then step back and analyze how as authors they invested each perspective with authority. The first part of this assignment is about telling their own stories - retracing their own biases. The second is about taking on and tracing others' biases. It is essential for these two parts of the assignment that students assume those different perspectives - reassume their own and take on others' for the first time-not simply describe them. It is equally important for the third part of the assignment that students step back and analyze how as authors they followed, or failed to follow, each bias faithfully. The demands of this assignment are the demands of constructivism and reflection: Students construe and construct their own understandings in relationship and in context and adapt their understandings and future choices for action based on the sense they make through those processes. Students assume various angles of vision and construct knowledge from distinct locations-a disciplinary perspective, an experiential base. This assignment aims to provide students with some new tools that they can use in future to construct knowledge and reflect on that process of construction, and it aims to give them an opportunity to develop some facility in using those tools.

\section{Example Two: Three Angles on Learning and Teaching}

"Curriculum \& Pedagogy" is a course required of Bryn Mawr and Haverford College seniors seeking certification to teach at the secondary level. Taken in the fall semester of their senior year, prior to undertaking student teaching in the spring, "Curriculum \& Pedagogy" offers 
pre-service teachers a context within which to engage in multiple dialogues and take an active role in forging their new identities as well as develop a critical awareness of those processes. Toward those ends, they work in collaboration with high school students and experienced teachers, maintaining an email exchange with a member of each of these constituencies within which they explore pedagogical theories and practices. They also develop over the course of the semester a portfolio in which they document and reflect on their evolving identities, educational theories, and plans for practice. Through these fora, the pre-service teachers both clarify and complicate the assumptions, beliefs, hopes, fears, plans, and goals they bring to their preparation to teach. (See Cook-Sather, 2006a, 2002a, 2002b, 2002c for other discussions of this course.)

An assignment I give on the first night of "Curriculum \& Pedagogy" has three parts. First, I ask the pre-service teachers to write a story of a time they learned something. It can be in school or out of school. It doesn't matter what it is that they learned. I want them simply to write about what comes to mind: any powerful learning experience. Then, I ask them to step back from the story they have written, to read it over, and to examine it through a critical lens. I ask them, What does your story tell you about yourself as a learner? This part of the assignment asks the pre-service teachers to shift frames: from a narrative retelling of a lived experience to a cognitive and analytical frame through which they assess those experiences from a critical distance. Finally, I ask the pre-service teachers to read both the story and what they have learned about themselves from it and to write about how they could become the teacher who could create a classroom in which students could learn in the way they describe. With this part of the assignment I ask them to shift frames yet again, this time to focus on the role of the teacher, to begin to imagine what is required of them to facilitate, not simply experience, education.

Like the assignment in "Finding the Bias," this assignment poses significant challenges to students and is itself about challenges; indeed, the assignment is premised on difficulty and unending complexity. It is intended to offer students a powerful way to approach the difficulty of teaching with a learning stance that gets them somewhere as learners without solving or collapsing difficulty. It is, in fact, impossible to be the teacher who can relate simultaneously to all the different students' different ways of learning; the assignment sets students up to see the richness and possibility of teaching diverse learners but also the daunting scope of the challenge. It also reminds me — both in the abstract and in particular details — about the same challenge of meeting my students' various needs as learners. 
Example Three: The Challenges You Face, the Challenges You Pose

"Talking Toward Techno-Pedagogy: A Collaboration Across Colleges and

Constituencies" is a workshop designed to encourage and facilitate-across college contexts as well as across roles assigned to different members of a college community_processes of communication and collaboration that start with thinking and talking through pedagogical issues at a basic level and then move toward explorations of how technology fits, or sometimes doesn't fit, with teaching. For each iteration of this workshop, the colleagues with whom I designed it and I invite teams of four, consisting of a faculty member, a rising junior in that faculty member's discipline, a librarian whose area of expertise is in, when possible, or near the faculty member's discipline, and an instructional technologist. During the workshop these teams are challenged to explore their roles and how they might work together to integrate technology into teaching and learning. On a deeper level they are challenged to unearth, think about, and talk through questions at the very root of education: What is learning? What should be learned? How? (For other discussions of this workshop see Cook-Sather, 2006a, 2001, and Shore, 2001).

On the second day of the workshop, participants engage in a three-part assignment. First, they meet and talk with others who occupy the same role (faculty, librarian, instructional technologist, or student) in order to clarify their current responsibilities and to think about their needs and goals. Second, we move to a potentially volatile aspect of the assignment: a conversation in which the same constituency groups must clarify and articulate the challenges they present or pose to others in their teaching and/or learning responsibilities and needs. For these first two parts of the assignment, we ask that within their constituency groups, participants address the following questions: What challenges do you face in working with the other groups represented here? and, What challenges do you think the other groups face in working with you? The third part of the assignment is a reframing of what was generated during the first two parts for a reporting back to the workshop participants as a whole-all constituency groups togetheron what each group generated in answer to the three questions. As with the other two assignments, the reframing required here is both a constructivist and a reflective move: It puts what is experienced and seen in a different frame and invites a different experience and seeing and, in turn, a different way of being as learners move forward. 


\section{The Qualities of the Assignments that Aim to Support Constructivism}

Reflecting across these assignments and the contexts in which I use them, I discern a number of shared qualities that support learners' engaging in constructivism and that support their development into reflective practitioners. Prior to undertaking this analysis, I had not been cognizant of these shared structural qualities. Rather, I had identified learning goals—particular kinds of experiences and insights, although not the particular experiences or insights themselves - that I wanted learners to have and to gain. I had been cognizant of the importance of creating opportunities for learners to enter different kinds of learning modes-experiential, analytical, metacognitive — but not that I was designing such similar structures across contexts. The similarity appears to me now both as consistency and potentially as confining — both to students and to me. All three of the assignments:

- are highly structured, have multiple parts, and include clear, explicit, and set guidelines that learners must follow but within which learners have significant freedom to forge and/or re-forge their own meanings and sense of themselves;

- ask learners to revisit familiar experiences from a new angle and/or to take on different perspectives from those to which they are accustomed;

- invite learners to reflect critically on and analyze their interpretations, actions, and relationships to others within the context of their own representations of those three things;

- challenge learners to see in a new light and take new responsibility for their interpretations, actions, and relationships in real life.

All three assignments require learners to move through the assignments' multiple parts in a definite sequence but within each part to bring their own individual experiences and perspectives to bear. This balance between structure and freedom is one that many pedagogues discuss (e.g., Duckworth, 1987; Freire, 1998; Tompkins, 1996). Within the tripartite assignments, the first move has to do with emotion-deep, sometimes disarming, emotional, lived and remembered experience. That I consistently have this component highlights for me the importance for learning that I attach to that kind of experience. I attach equal importance to stepping back from that lived, emotional mode to a more analytical mode. And finally, I emphasize the importance of meta-analysis, metacognition, in the third step of these assignments. 
My intention in imposing strict parameters and structuring the move from emotional through analytical to metacognitive is to prevent learners from feeling overwhelmed by an open field of possibilities and to prevent them from attempting to engage in experiential, analytical, and metacognitive modes simultaneously. What I find in analyzing the structures I have created across assignments is that one of my pedagogical convictions is that students need bounded frames within which to explore and that they benefit from taking up modes serially rather than simultaneously. Such structure, I believe, invites students to draw on their own experiences and construct their own understandings and, through doing so, to revise their sense of themselves. Questions that arise, though, include, What is gained and what is lost in serial versus simultaneous processing? and What can the role of thinking be in relation to feeling, language, etc.? An underlying conviction that I hold, as evidenced in this structure, is that to be actively engaged you have to be present, in the moment; you cannot constantly be calling yourself out and analyzing what you are getting. The question that my consistency in designing these assignments across contexts raises for me is whether I manage too extensively the steps in learning I aim to support-whether I prevent certain generative interactions across experiential, analytical, and metacognitive modes by separating them.

In addition to being highly structured, all three assignments ask learners to revisit familiar experiences from a new angle and/or to take on different perspectives from those to which they are accustomed. The multiple-perspectives assignment in "Finding the Bias" requires that each student choose and retell a story from her life first from her own perspective, then tell the same story from the perspectives of two others who shared the experience, and then analyze the authority with which she invested each version. The three-part assignment in "Curriculum \& Pedagogy" requires that each pre-service teacher first recount a narrative of experience, then analyze that narrative for what it reveals about that learner's needs, and finally imagine the qualities of a teacher that would meet that learner's needs. The assignment in "Talking toward Techno-Pedagogy" asks participants first to reflect on the challenges to collaboration they face, then to imagine the challenges they pose or present to others, and finally to reframe and report to other constituencies what they have generated and the implications for collaboration. All three assignments ask learners to start with what is most experience-based and self-centered (in both the positive and the negative senses of that term), then either to shift from their own perspective to someone else's or to shift from one perspective within themselves to another (e.g., personal to 
analytical), and finally to shift to imagining how the insights they have gained from experiencing and reflecting on the first two shifts might inform their sense of themselves and their relationships with others in terms of their responsibility to both, as well as the actions they might take in regard to both. The assignments' insistence on repeatedly shifting perspectives reveals my underlying conviction that learners should not be fixed or wedded to any single angle of vision and to the perspective that angle affords. The question this quality of the assignments raises for me now is whether such repeated shifting can become too destabilizing or vertiginous. Denied steady moorings while trying to develop understandings, might students feel too adrift? Or might there need to be more variation in the extent of the mooring-with some students needing more mooring, some less? This variation might be understood as a dimension of diversity. These reflections also raise the question of the place of commitment to a philosophy, goal, or self-story in the call for flexibility.

The structure of the assignments and the multiple perspectives learners are required to assume within them are intended to support learners as they critically reflect on and analyze their interpretations, actions, and relationships to others within the context of representations of those. Furthermore, they aim to support learners as they take responsibility for their interpretations, actions, and relationships in real life. The multiple perspectives assignment starts with inviting and validating students' own perspectives. It is easiest to start with what one thinks one knows, although one doesn't always "know," in the sense of being able to represent in a public forum, one's own story. Doing these things takes practice, courage, and the development of voice, all of which are important to learners gaining a sense of authority. A student articulates this point well: "It was essential that I wrote my account first to establish myself and my bias." This assertion of her own narrative gave her the confidence to turn to others' versions: "Because I felt confident that my own story was my own personal 'truth,' I was no longer afraid of finding a story that was different than my own interpretation because my story was already strongly established and I believed in its validity." Thus starting with what one (thinks one) knows appears to be essential to creating both confidence in one's own perspective and openness to others' perspectivesshifting, perhaps, notions of self as center to relationship or community as center.

Once students have settled on their own initial version of the story, they must attempt to tell two other versions. Students approach this part of the assignment with known voices in their heads; the perspectives students attempt to represent belong, for the most part, to people they 
know — family, friends — and issue from contexts with which they are familiar. Students' first concern is with finding or choosing the right words in which to render those familiar voices. They pose and answer questions for themselves such as, "Would he use that word?" and "Is that something she would say?" Many discover that "describing a person and how they think and then thinking like them are very different." Another student explains that after writing her version and the two others, she checked with one of the people whose perspective she rendered, and she discovered how much his recollection differed from hers. She recognized, with a jolt, that "I expected his memory to support my own." Reflecting on this startling awakening, she writes: "[B]efore even writing the perspectives, I had subconsciously centered the story around my experiences, viewing [his] and [his mother's] renditions as supplementary. As the tailor of these pieces, the reconstructor of these events, I inevitably awarded myself more emotional authority, and the other two characters only possess the thoughts and feelings I allow them to have." This recognition, gained in the final phase of the assignment but prompted by the second phase, is catalyzed by this student's attempt to assume and render a perspective other than her own, critical analysis of that attempt, and willingness to rethink based on what she learned.

In the final phase of the assignment, students come to realizations that have implications for their lives, not just the texts they have composed. One writes: "I have been forced to acknowledge the validity of my sister's point of view and my mother's behavior. The worst part, seeing all these events in retrospect, is that had I realized what I was doing at the time and how damaging it was to my own situation, I would have acted differently." Stepping back and analyzing the authority of each perspective leads students to see "how narrow-minded I had been all along, how badly afflicted with tunnel vision." These students have not simply told their stories, told other stories, and compared the different versions; they have re-inhabited and inhabited for the first time various perspectives, and they are transformed by this process. Like the requirement that students revisit familiar experiences from a new angle and/or to take on different perspectives from those to which they are accustomed, the requirement that they reflect critically on and analyze their interpretations, actions, and relationships to others within the context of their own representations of those three things is both potentially enlightening and disturbing. While it has the potential to deepen their understanding of the complexities of interpretation, representation, and action, it could also be disabling-overcomplicating to the 
point of prompting paralysis of interpretation and action, particularly because it privileges verbal/linguistic ways of knowing.

The three-part assignment in "Curriculum \& Pedagogy" calls for a different kind of perspective shifting and self-transformation-one based on professional roles as well as personal differences. In response to the first challenge - to write a story about a time that they learned something-I want pre-service teachers to listen to what comes first to mind in their role as a learner. They write about all varieties of things: learning to tie their shoes, learning to ride a bicycle, learning to drive a car, learning to write a research paper, learning to communicate better with a sibling. Their stories range across contexts, characters, and critical incidents, but all are deeply felt experiences that stand out in these pre-service teachers' minds as particularly memorable moments of learning. Thinking creatively, unconsciously even, simply concentrating on the experience they had, they get at their most basic needs and preferences as learners. I ask them to focus first simply on an experience because I think that if I were to ask them to complete all three parts of this assignment at once, their analytical minds might obscure their more creative and profound insights, although, at the same time, analysis might deepen naïve insights.

After they have composed their stories, asking them then to step back and engage in analysis of those stories aims to accomplishe a number of things: to help them shift from the emotional/experiential to the analytical and get the most out of both, to validate their personal stories as texts worthy of study, and to model a version of the shift they will need to make as they transform themselves into teachers. Here is a sample of the analyses pre-service teachers write of their stories: "I need someone to show me how to do something first, then I need to try it myself, and I need a lot of pushing as well as support." "I am often afraid to try something new. I'm more comfortable sticking with what I know. So when I have to learn something new, I can get very disoriented; it's like I forget everything I already know. So I need someone to help me make connections between what I already understand and the thing I am supposed to learn." "I am most comfortable figuring things out on my own and I don't like it when someone looms over my shoulder or keeps offering advice."

The final phase of the activity strives to make the need for transformation both of experiences and of selves concrete: it challenges pre-service teachers to imagine themselves moving from someone positioned primarily as a student to someone positioned primarily as a teacher. Their individual insights include these: "I need a teacher who will constantly monitor 
my work." "I need a teacher who will leave me alone." "I need a teacher who is very wellorganized and a class that is tightly run." "I need teachers who are tough on me." "I need teachers who are gentle and ease me into things." Identifying these needs and hearing the needs of others - always various, often in conflict with one another-often clarifies for these preservice teachers that they will always need to re-construe and re-construct themselves not once but again and again. As one pre-service teacher puts it: "There is no "defined formula [for being a teacher]; I will have to struggle with this issue throughout the rest of my teaching career."

With each shift in perspective this assignment requires, learners move further from who they currently feel they are toward who they must imagine themselves becoming. The subject around which they shift perspectives is the same-a learning experience-but the critical angles on that experience and the identity the learners are invited to assume as the angle shifts aim to prompt a recognition of the necessity of repeated reconstructions of themselves within their own experiences. These shifts also are intended to prompt the pre-service teachers to see that they will need to facilitate such processes for learners themselves. Like the realization I aim to foster among students in "Finding the Bias" that acts of textual rendering have real-world as well as interpretive consequences, the realization I hope pre-service teachers will have in "Curriculum $\&$ Pedagogy" is that their interpretations of learners have very concrete pedagogical consequences. The connection to constructivism here is that construing and constructing meaning are not abstract processes; they make not only meaning but also realities. The connection to reflection is that it is only by stepping away from those made and lived realities and looking at them with a critical eye that learners can recognize the consequences. The question this quality of the assignments raises is, again, how much might this recognition lead to informed practice and how much to overinterpretation and attendant inability to act, even relativism.

The assignment from "Talking Toward Techno-Pedagogy" first affords professors, instructional technologists, librarians, and students the opportunity to make connections, gain insights, and perhaps commiserate among themselves — as people with the same institutional perspective. Through this part of the assignment, learners often experience a sense of reassurance, validation, shared experience. As one student wrote in reflecting on this part of the assignment: "We have a much better understanding in my group of the roles of each person in the group and of the value of collaboration."It is far easier to find fault with others than turn a critical lens on the self. The second part of the assignment—which asks learners to do the 
latter-builds on the comfort the first part of the assignment establishes and challenges learners to assume a different perspective on themselves and others. Having felt reassured and validated, learners are more willing to look critically at themselves, and take a perspective on their identities and forms of participation that might call both into question. Reflecting on this part of the assignment, a librarian wrote about "the recognition that emerged in the minds of different groups about what it is that the others do and what they have to offer each other." This clarification led to rethinking people's roles and responsibilities as "myths and stereotypes were broken down." Through "challenging assumptions and preconceptions of my work within education and changing views of my own work," one librarian explained, "[I] actually came to value my work more." Through realizing what others could contribute to his pedagogical efforts, one professor was grateful to realize "all of these wonderful ideas can come to fruition without me doing and being everything." Through both clarifying what they believe to be true and clarifying what is not true and what is possible, participants begin to imagine how they could become more responsive to others as well as more fully realize their own potential.

Drawing on their reflections on the challenges they face and the challenges they pose, participants move to a third perspective: one from which they must report their explorations to an audience composed both of those who share their perspectives and those who don't. Many articulate their ignorance regarding the identities and responsibilities of others. A student reports back to the whole group: "I think the general idea [among us] about the [instructional technologists] is we have no idea what they do. We just don't know, we don't know who they are, we don't know where their offices are we don't know what questions to ask, we don't speak the same language." A librarian reports the challenge her constituency group feels they pose to others: "We need to do a better job of articulating what it is that we do." Drawing on a combination of the first two parts of the assignments, another librarian discusses the challenges that faculty and librarians pose to one another: “[Faculty] definition of instruction hasn't perhaps changed whereas the instruction has and we need to find out ways to reach that group on our campuses in order to help them realize what it is that we do."

The challenges-you-face-challenges-you-pose assignment points up immediate implications for daily life. Librarians talk about how they have re-construed and re-constructed themselves. One explains: "We moved from roles of reactivity to proactivity." The goal of many of the instructional technologists who participate in "Talking Toward Techno-Pedagogy" is "an 
evolved role on our campuses. . . over time, whether it's through our own actions or by changing other people's perceptions of us, that we could have more sophisticated involvement with teaching and learning issues." A faculty member explains, reporting back from his constituency group: "When we talked about questions of responsibility and authority we focused, necessarily, on the faculty's sense of being the expert people about the content of the course. Then the question that we asked - to which we had varying answers, quite varying answers-was whether technology has the potential for redefining what the content of the course is and therefore for redefining the issues of authority and responsibility for the course. If we're redefining the nature of the subject matter of the course, then does the relationship between faculty, student, librarian, technologist become a different kind of relationship?" As these reflections suggest, this assignment challenges participants to turn a critical lens on themselves and to shift critical discourse regarding collaboration from identification of the problems others pose to identification of what each participant, individually and as a member of a particular constituency, poses to others and how, once these are understood, everyone can make themselves better collaborators, better learners.

All these assignments require learners to construct their own understandings and proceed based on those constructions. Learners are active throughout these processes, making decisions at every point that affect not only their understanding or knowledge but also their participation in the world. Furthermore, engaging in these processes makes learners more aware, more cognizant, and more inclined to embrace new ideas, representations, and relationships as they encounter and construct them. These are the virtues of constructivism that I am trying to foster; they guide me as outcomes: My goal is to make learners more skilled as constructivists and reflective practitioners. The questions that looking critically at these assignments raise for me center around whether in requiring so many shifts of mode and angle, I might destabilize rather than deepen student understanding. Dewey argued that thinking — and, ultimately, learning —is “occasioned by an unsettlement and it aims at overcoming a disturbance" (1916/1980, p. 336), but at what point does "unsettlement" lead to inability to act or even to care? 


\section{Complicating Reflections on Pedagogical Commitments that Support Constructivism}

In reflecting on these assignments and on the qualities they have in common, I attempted to bring into sharper focus the pedagogical commitments that underlie them and raised questions that might be taken up in further reflection. These regard:

- how learners are conceptualized - their identities and capacities;

- the creation of the spaces in which learners engage; and

- responses to learners' efforts.

\section{How Learners Are Conceptualized}

The assignments discussed in this article are built on the premise that learners bring complex, attenuated identities to their educational experiences; they are individual, social selves both self-defined and "crafted through linguistic exchanges with others" (Harter, 1996, p. 3). Their identities are "a starting point—not an ending point...a vehicle for multiplying and making more complex" their sense of themselves and their relationships (Ellsworth, 1992, p. 113). The assignments are also structured according to the assumption that learners can and should grow and change, transform themselves, not into entirely different people but into new versions of themselves through processes supported by teachers but within which the learners are both the changers and the changed. The question this pedagogical commitment raises is whether learning need be about change. Might it sometimes also be about reaffirming, deepening, strengthening what one already knows and believes - also dimensions of change, but into more of something, rather than something other?

\section{The Creation of the Spaces in Which Learners Engage}

In order to engage in constructivism, learners need to have spaces for themselves and their fellow learners in addition to the teacher within which to actively shape and guide their own and others' learning. Structures that de-center the teacher and approaches that do not teach learners concepts, such as identity and authority, but rather provide opportunities to reframe already lived experiences and understandings help students develop their own new vocabularyand thus ways of thinking - within which to analyze their own experiences, understandings, and participation. Within a reflective and analytic structure that is clear (with guidelines) but also open so that learners can fill it with their own concepts, experiences, concerns, students have an 
opportunity to learn a method of making meaning, not a dogma or set of principles. A question that such an approach raises is whether this removes the teacher too much from the learning process. Does it deny students sufficient support or even direction that some learners want and need?

\section{Responding to Learners}

To engage in constructivism, students need both structure and challenge. They need first to raise their awareness of the need for change and growth while not becoming overly selfconscious. By highlighting this need, and by encouraging and supporting learners as they make initial attempts, a teacher can convey to them that they can, in fact, engage in these processes in meaningful ways. As the learning unfolds, a teacher can encourage learners to make a learning occasion out of whatever happens, not accepting learners' efforts to take up simple or prescriptive ways of thinking or approaches without challenging them to analyze critically and embrace in an informed way the tenets of those ways of thinking and approaches. The greatest challenge to such an approach is when learners make meaning that a teacher does not find acceptable_-examples I have encountered include students asserting theirs as the only truth; preservice teachers committing themselves to teaching all students in the same way; and participants in "Talking toward Techno-Pedagogy" thinking that other people pose all the challenges to collaboration. These moments call for the person in the teaching or facilitating role to rethink herself as much as for learners to do the same-to revisit assumptions and commitments, question them as we ask learners to do, and work to create either another version of words, ideas, and perhaps selves in relation to the stances the learners take up or else accept that our respective words, ideas, or stances are divergent.

\section{Conclusion}

The assignments and the pedagogical convictions upon which I reflect here challenge us as teachers to create opportunities for learners to construe and construct not only meaning but also themselves. They challenge us to relinquish traditional forms of power and control, to follow as well as lead, to listen carefully to others' perspectives as well as carefully share our own, and to allow ourselves to be destabilized by both these reciprocal processes. Rather than allowing us to be inured, inflexible, certain, or set, they invite us to assume the same risks of 
interpretation, expression, and revision we ask learners to take in the process of education. In reflecting on the ways I endeavor to meet these challenges, I am faced with a new set of questions regarding the complexities of such efforts, which I have discussed throughout ad to which I return in this concluding section.

Assignments that are multifaceted (not necessarily composed of three-parts, but of multiple parts), draw on or evoke multiple perspectives (rather than stay confined to single view), demand critical reflection and deep analysis (rather than admit of easy interpretation), and have connections to and implications for real life (rather than remain simply theoretical or purely abstract) can facilitate both constructivism and reflection. Such assignments, like facilitation of learners' engagement with them, can foster complicated, sometimes contradictory, and usually deeply meaningful learning. They also have the potential to be confusing, destabilizing, disorientating, and even paralyzing.

One of the most significant challenges of this kind of constructivism is that its products can be difficult to assess; it is harder to affix labels to what people have learned. Such approaches also put one at risk for being misunderstood because they place one at odds with more conventional pedagogical approaches. Embracing a radically student-centered and constructivist set of goals requires that one struggle with their misfit with more standard ways to address learners and learning.

What learners construct within the structure of the assignments I discuss here is distinctive to them and their context and is productively put into relationship with what others construct. For them too, then, the mirror is always in motion: Their perspectives are always shifting and exist in relation to others' shifting perspectives. Anyone who takes up the approaches I discuss here also must continue to shift perspective as he or she takes up new angles of vision on this work. What I have learned through this particular reflection is that in striving to balance structure and freedom, I am reminded that I have particular values and goals that are congruent with the principles of constructivism but that limit the possibilities for meaning making. By so carefully constructing the parameters within which learners construct their own meaning and at the same time requiring repeated shifting of angles of vision, I might be missing or disallowing other forms of construal and construction.

Like the critical reflection and constructivism that provide the frame and focus of this discussion, the assignments upon which I reflect here require that we all be willing to take on, 
again and again, the demanding work of recognizing emotional investment, making intelligent meaning, and taking responsible action. Looking in the mirror in motion at the pedagogical commitments I have surfaced reveals how what those commitments mean shifts and must be continually questioned if they too are to remain responsive and educative. 


\section{References}

Colton, A. B., and Sparks-Langer, G. M. (1990). A conceptual framework to guide the development of teacher reflection and decision making. Journal of Teacher Education 44, 1 (January/February) 45-54.

Cook-Sather, A. (2006a). Education is translation: A metaphor for change in learning and teaching. Philadelphia, PA: University of Pennsylvania Press.

- (2006b). Production, cure, or translation?: Rehumanizing education and the roles of teacher and student in us schools and universities. Forum 48, 3, 319-326.

- (2003b). Education as translation: students transforming notions of narrative and self. College Composition and Communication 55, 1 (September), 91-114.

—. (2002a). Teachers-to-be learning from students-who-are: reconfiguring undergraduate teacher preparation. Stories of the courage to teach: honoring the teacher's heart. Ed. Sam M. Intrator. Jossey-Bass Publishers.

- (2002b). Re(in)forming the conversations: student position, power, and voice in teacher education. Radical Teacher 64, 21-28.

- (2002c). "A teacher should be. ..": when the answer is the question. Knowledge Quest 30, 5 (May/June), 12-15.

- (2001). Between student and teacher: teacher education as translation. Teaching Education 12, 2, 177-190.

- (2001). Unrolling roles in techno-pedagogy: Toward collaboration in traditional college settings. Innovative Higher Education 26, 2, 121-139.

Cook-Sather, A., Rowe, K, \& Shore, E. (2001). Finding the biases in a community of scholars. Liberal Education 88,1 (Winter), 48-53.

Davis, B., \& Sumara, D. (2002). Constructivist discourses and the field of education: problems and possibilities. Educational Theory 52, 4, 409-428.

Dewey, J. (1933). How we think. Buffalo, NY: Promethues Books (Original work published in 1910).

- (1916). Democracy and Education.

Dreier, O. (2003). Learning in personal trajectories of participation. Theoretical psychology: critical contributions. Ed. Niamh Stevenson, H. Lorraine Radtke, Renè Jorna, \& Henderikus J. Stam. Toronto: Camptus Press. 20-29 
Duckworth, E. (1987). The virtues of not knowing. "The having of wonderful ideas" and other essays on teaching and learning. New York: Teachers College Press. 64-69.

Elbaz, F. (1987). Teachers' knowledge of teaching: Strategies for reflection. Educating teachers: Changing the nature of pedagogical knowledge, ed. John Smythe Philadelphia: Farmer Press.

Ellsworth, E. (1992). "Why doesn't this feel empowering? working through the repressive myths of critical pedagogy. Ed. Carmen Luke and Jennifer Gore. Feminisms and Critical Pedagogy. New York: Routledge.

Harter, S. (1996). Historical roots of contemporary issues involving self-concept. Ed. Bruce A. Bracken. Handbook of self-concept: developmental, social, and clinical considerations. New York: John Wiley \& Sons, Inc. 1-37.

Imel, S. (1992). Reflective practice in adult education. ERIC Digest No. 122 (Columbus, Ohio, ERIC Clearinghouse on Adult Career and Vocational Education.

Kroll. L. R. (2005). Constructivism in teacher education: Rethinking how we teach teachers. In L.R. Kroll, R. Cossey, D. M. Donahue, T. Galguera, V. K. Laboskey, A. E. Richert, and P. Tucher, Teaching as principled practice: Managing complexity for social justice (pp. 57-80). Thousand Oaks, CA: Sage Publications.

Kroll, L. R., and Galguera, T. (2005). Teaching and learning to teach as principled practice. In L.R. Kroll, R. Cossey, D. M. Donahue, T. Galguera, V. K. Laboskey, A. E. Richert, and P. Tucher, Teaching as principled practice: Managing complexity for social justice (pp. 1-16). Thousand Oaks, CA: Sage Publications.

Lesnick, A. (2005). The mirror in motion: Redefining reflective practice in an undergraduate fieldwork seminar. Reflective Practice 6, 1, 33-48.

Packer, M. (2001). Changing classes: school reform and the new economy (learning in doing: social, cognitive \& computational perspectives). New York; Cambridge University Press.

Reiman, A. J. and Thies-Sprinthall, L. (1998). Mentoring and supervision for teacher development. New York: Longman.

Rodgers, C. (2002a). Defining reflection: Another look at John Dewey and reflective thinking. Teachers College Record 104, 4, 842-866. . (2002b). Seeing student learning: Teacher change and the role of reflection. Harvard Educational Review 72, 2, 230-253. 
Richert, A. (1990). Teaching teachers to reflect: A consideration of programme structure. Journal of Curriculum Studies 22, 6, 509-527

Rudney, G. L., and Guillaume, A. (1990). Reflective teaching for student teachers. The Teacher Educator 25, 3, 13-20.

Schön, D. A. (1983). The reflective practitioner: How professionals think in action. New York: Basic Books.

Shapiro, A. (2003). The latest dope on research (about constructivism): Part II: On instruction and leadership. International Journal of Educational Reform 12, 1 (Winter), 62-77.

Shapiro, A. (2002). The latest dope on research (about constructivism): Part I: different approaches to constructivism-What it's all about. International Journal of Educational Reform 11, 4 (Fall), 347-361.

Shore, E. (2001). Liberal arts education in the new millennium: beyond information literacy and instructional technology. Moveable Type: The Newsletter of the Mark O. Hatfield Library. Willamette University.

Tompkins, J. (1996). A life in school: what the teacher learned. Reading, MA: Addison-Wesley Publishing Co.

Von Glaserfeld, E. (1996). Introduction: Aspects of constructivism. In C. T. Fosnot (Ed.) Constructivism: Theory, perspectives, and practice (pp. 3-7). New York: Teachers College Press.

Wortham, S. (2004). The interdependence of social identification and learning. American Educational Research Journal 41, 3 (Fall), 715-750.

Yinger, R. J. (1987). Learning the language of practice. Curriculum Inquiry 17, 3, 293-318. Zeichner, K. M., and Liston, D. P. (1987). Teaching student teachers to reflect. Harvard Educational Review 57, 1, 23-48. 